\title{
Physiological Indicators in Two Lettuce Cultivars Under Saline Stress
}

\author{
Marcos Antonio Dantas de Oliveira ${ }^{1}$, Paulo Torres Carneiro ${ }^{1}$, Maria Claudjane Jerônimo Leite Alves ${ }^{1}$, \\ Thayse Valéria e Silva ${ }^{1}$, Gilberto da Cruz Gouveia Neto ${ }^{2}$, Thiago José Rocha Matos ${ }^{3}$, Mayra Andrade Souza ${ }^{3}$, \\ Aldenir Feitosa dos Santos ${ }^{3}$, João Gomes da Costa $^{4} \&$ Jessé Marques da Silva Júnior Pavão ${ }^{3}$ \\ ${ }^{1}$ Postgraduate Program in Agriculture and Environment, Alagoas Federal University, Arapiraca Campus, Brazil \\ ${ }^{2}$ Alagoas Federal Institute, Santana do Ipanema Campus, Brazil \\ ${ }^{3}$ Postgraduate Program in Environmental Systems Analysis, Cesmac University Centre, Campus IV, Brazil \\ ${ }^{4}$ Food and Territory Research Unit, Brazilian Agricultural Research Corporation (EMBRAPA), Maceió, Brazil \\ Correspondence: Jessé Marques da Silva Júnior Pavão, Postgraduate Program in Environmental Systems \\ Analysis, Cesmac University Centre, Campus IV, Street Prof. Ângelo Neto, 51-Farol, Zip Code: 57051-530 \\ Maceió, AL, Brazil. Tel: 55-(82)-3215-5000. E-mail: marquesjjunior@gmail.com
}

Received: May 14, 2020

doi:10.5539/jas.v13n4p52
Accepted: February 13, $2021 \quad$ Online Published: March 15, 2021

URL: https://doi.org/10.5539/jas.v13n4p52

\begin{abstract}
Lettuce (Lactuca sativa L.) is considered as the main leafy vegetable in Brazil. In the last decades, there had been many changes in the predominant varietal types in the country, however, issues regarding the use of saline water inhibit the growth by the osmotic effect. The aim of this study is avaliate the effect of water salinity on physiological in lettuce cultivars. The experiment was carried out at the Alagoas Federal University, Arapiraca Campus, in a completely randomized design and with a $5 \times 2$ factorial scheme, with six replications. Five treatments of water salinity levels were analyzed (ECw: $0.14,1.54,2.94,4.34$, and $5.74 \mathrm{dS} \mathrm{m}^{-1}$ at $25^{\circ} \mathrm{C}$ ) in two types of lettuce crops (Saia Véia and Vitoria Verdinha). Stomatal conductance, net photosynthesis, transpiration rate, water use efficiency, leaf temperature, and green index were assessed at 10, 20, and 30 days after the application of the treatments. The saline stress caused by the increase in saline concentrations decreased the photosynthesis and transpiration rates, which were associated with the reduction of stomatal conductance in both cultivars. Nevertheless, Saia Véia cultivar was higher tolerance in all tested saline levels compared to Vitória Verdinha. The green index for Vitoria Verdinha was seven times higher when compared to Saia Véia from the lowest to the highest saline levels. The cultivars differ in salt sensitivity, which could be useful for producers to choose the cultivar that is most adapted to the region and breeders regarding improvement prospects for adaptation of the lettuce under saline stress. In addition to osmotic stress, which is the first to happen, there are others.
\end{abstract}

Keywords: Lactuca sativa L., plant ecophysiology, salinity

\section{Introduction}

Soil salinity and irrigation water have been arousing interest since they are regarded as worldwide issues in agricultural production. It is estimated that soils affected by salt occupy about $10 \%$ of land surface and $50 \%$ of irrigated land in the world (Ruan et al., 2010). The effects of salinisation can be observed in numerous vital ecological and non-ecological soil functions. Drivers of salinisation can be detected both in the natural and man-made environment, with climate and the foreseen climate change also playing an important role. Global annual losses in agricultural production due to salt-affected soils can be as high as US\$ 12 billion (Qadir et al., 2008; Flowers et al., 2010). The salinization process is due to environmental characteristics and anthropic actions (Daliakopoulos et al., 2016). Natural characteristics include the transport of salt sediments from salinized areas to unsalted sites; actions of ascent by capillarity of the soils to surface; high rates of evapotranspiration, among other factors (Pedrotti, 2015; Walter et al., 2018).

Soil salinity, whether natural or human induced, is a major geo-hazard in arid and semi-arid landscapes. In agricultural lands, it negatively affects plant growth, crop yields, whereas in semi-arid and arid non-agricultural areas it affects urban structures due to subsidence, corrosion and ground water quality, leading to further soil erosion and land degradation (Abuelgasim \& Ammad, 2019). 
The Brazilian Semi-arid (BSA) region known as the Sertão is located in the Northeast part of the country and is one of the two areas most affected by climate change in Brazil (Seddon et al., 2016). The Sertão is characterized by the unique Caatinga biome - mostly consisting in deciduous forests, with uneven rainfall patterns and land distribution, climatic variation and social disparities. Several public policies have been adopted since 1877 to address the issues of the region, predominantly related to water scarcity; yet, the Sertão remains marginalized. Family farmers are the area's most vulnerable social group, in particular diffuse farmers (Machado \& Revere, 2018). In these regions, agricultural activity has been a great challenge, especially for family farmers who do not have technical assistance and, plant empirically, leafy vegetables that are highly sensitive to soil salination (Qin et al., 2010; Medeiros et al., 2016).

Among the leafy vegetables sensitive to soil salinity, lettuce stands out (Lactuca sativa $\mathrm{L}$.), consumed worldwide and is an important crop of agrosystems in semi-arid regions (Ribeiro et al., 2003). Saline environments are mainly located in coastal zones, but they can also be found inland. Natural causes for inland salinization are the presence of salt-rich rainwater or saline groundwater, high evaporation and low precipitation. In such regions, upward-directed soil water movement by capillary rise is a dominant process and rates of precipitation are too low to leach out salts. This leads to an accumulation of salts within the topsoil or at the soil surface. Typically, such conditions are found in arid regions (Colombani, Mastrocicco, \& Giambastiani, 2015; Walter et al., 2018).

Accumulation of salts in the soil can alter the water uptake by plants, reducing assimilation and nutrient utilization (Parida \& Das, 2005; Tavakkoli et al., 2012). The accumulation of $\mathrm{Na}^{+}$and/or $\mathrm{Cl}^{-}$in chloroplasts, affects important biochemical and photochemical processes involved in photosynthesis and gas exchange (Xu \& Mou, 2015; Amorim et al., 2010). Plants on the basis of adaptive evolution can be classified roughly into two major types: the halophytes (that can withstand salinity) and the glycophytes (that cannot withstand salinity and eventually die). Majority of major crop species belong to this second category. Thus salinity is one of the most brutal environmental stresses that hamper crop productivity worldwide (Flowers, 2004; Munns \& Tester, 2008). In addition, the tolerance a crop has to salinity can vary between genotypes of the same species as well as the plant's development stage (Gheyi et al., 1997).

According to the researchers Gupta \& Huang (2014) a comprehensive understanding on how plants respond to salinity stress at different levels and an integrated approach of combining physiological tools with and biochemical techniques are imperative for the development of salt-tolerant varieties of plants in salt-affected areas. Recent research has identified various adaptive responses to salinity stress at physiological levels, although mechanisms underlying salinity tolerance are far from being completely understood. Lettuce is considered 'moderately sensitive' to salinity and its potential yield is reached when the electrical conductivity of the saturated extract reaches the threshold value of $1.3 \mathrm{dS} \mathrm{m}^{-1}$, with a $13 \%$ reduction in yield per unit increase of salinity above the value (Ayers \& Westcot 1991). In this context, this paper aims evaluate the effect of water salinity on physiological in lettuce cultivars.

\section{Methods}

\subsection{Environment and Meteorological Parameters}

The experiment was carried out in a greenhouse with $50 \%$ shading and anti-UV treatment, located at the Alagoas Federal University (UFAL), Arapiraca Campus (latitude 09 $41^{\prime} 53.6^{\prime \prime} \mathrm{S}$, longitude 36 $41^{\prime \prime} 26.3^{\prime \prime} \mathrm{W}$ and $244 \mathrm{~m}$ altitude) Northeast of Brazil. The outside meteorological parameters in the greenhouse obtained from the university's automatic weather station (maximum, minimum temperature, precipitation and global radiation). The inside meteorological parameters in the greenhouse: photosynthetically active radiation obtained from spectroradiometer (Apogee, model SS-110) which measures received by pots were performed in two moments: 7:00 a.m. to 11:00 a.m. and 12:00 p.m. to 4:00 p.m. The temperature and humidity were measured with the aid of a thermo-hygrometer (model HT-208) and it was installed at the center of the protected environment, $1.0 \mathrm{~m}$ above from the ground level.

The climate of the region is of the AS tropical type (rainy with a dry summer), according to the classification of Köppen (1948) and Dubreuil et al. (2018). It features two well established climatic seasons: a warm and dry summer, with occasional rainfall (September to March), and wet and rainy winter (April to August). The mean annual precipitation ranges from 750 to $1000 \mathrm{~mm}$ (Xavier \& Dornellas, 2005).

\subsection{Lettuce Varieties}

Sáia véia: The cycle of 35 to 40 days after transplantation. Optimum germination range: $10-27{ }^{\circ} \mathrm{C}$. Plant with moderately wrinkled, large, and elliptical smooth leaves, with light green color. It does not form a head and has white seeds. 
Vitória verdinha: The cycle of 35 to 40 days after transplantation. Optimum germination range: $10-27{ }^{\circ} \mathrm{C}$. It has smooth leaves, slightly wrinkled and soft texture, dark green in color. It does not form a head and has white seeds.

These two lettuce cultivars used in this experiment are the most planted in the APL region (Aranjo Produtivo Local) in the municipality of Arapiraca in Northeast of the Brazil. The APL is reference in the production of fruits and vegetables and it distributes to consumer markets in Brazil.

\subsection{Soil Analyses}

A soil sample of $1.0 \mathrm{~kg}$ was collected at the UFAL area in a $0-0.20 \mathrm{~m}$ layer that represents the effective depth of the lettuce root system. Samples were sent for chemical and physical analyses, respectively, to the Soil Fertility Laboratory and Soil Physics Laboratory (Department of Environmental Resources, School of Agronomic Sciences, UNESP, Botucatu, São Paulo).

Soil analysis classified it as a sandy loam soil and showed the following features: $\mathrm{pH}$ in water of $6.3 ; 18 \mathrm{mg} / \mathrm{dm}^{3}$ of P; $3.6 \mathrm{mmol}_{\mathrm{c}} / \mathrm{dm}^{3}$ of $\mathrm{K} ; 44 \mathrm{mmol}_{\mathrm{c}} / \mathrm{dm}^{3}$ of $\mathrm{Ca} ; 16 \mathrm{mmol}_{\mathrm{c}} / \mathrm{dm}^{3}$ of $\mathrm{Mg} ; 0 \mathrm{mmol}_{\mathrm{c}} / \mathrm{dm}^{3}$ of Al; $11 \mathrm{mmol}_{\mathrm{c}} / \mathrm{dm}^{3}$ of H$^{+}$ $\mathrm{Al} ; 17 \mathrm{mg} / \mathrm{dm}^{3}$ of $\mathrm{Fe} ; 4.7 \mathrm{mg} / \mathrm{dm}^{3}$ of $\mathrm{Mn} ; 0.5 \mathrm{mg} / \mathrm{dm}^{3}$ of $\mathrm{Cu} ; 1.4 \mathrm{mg} / \mathrm{dm}^{3}$ of $\mathrm{Zn} ; 25 \mathrm{mmol}_{\mathrm{c}} / \mathrm{dm}^{3}$ of S; 63 $\mathrm{mmol}_{\mathrm{c}} / \mathrm{dm}^{3}$ of base sum (BS); $85 \%$ base saturation (V), $74 \mathrm{mmol}_{\mathrm{c}} / \mathrm{dm}^{3}$ cation exchange capacity (CEC) and 18 $\mathrm{g} / \mathrm{dm}^{3}$ organic matter (OM). The physical analyzes quantified the levels of sand (484 g/ $\left.\mathrm{kg}\right), \mathrm{silt}(62 \mathrm{~g} / \mathrm{kg})$, and clay $(162 \mathrm{~g} / \mathrm{kg})$, soil with a medium texture.

\subsection{Water Analyses}

The water (control) used in the experiment had the following elements: $3 \mathrm{mg} / \mathrm{L}$ of $\mathrm{N} ; 0.3 \mathrm{mg} / \mathrm{L} \mathrm{of} \mathrm{P;} 12 \mathrm{mg} / \mathrm{L}$ of $\mathrm{K} ; 5 \mathrm{mg} / \mathrm{L}$ of $\mathrm{Ca} ; 3 \mathrm{mg} / \mathrm{L}$ of $\mathrm{Mg} ; 4 \mathrm{mg} / \mathrm{L}$ of S; $4.6 \mathrm{mg} / \mathrm{L}$ of Na; $0.12 \mathrm{mg} / \mathrm{L}$ of B; $0 \mathrm{mg} / \mathrm{L} \mathrm{of} \mathrm{Cu} ; 0 \mathrm{mg} / \mathrm{L} \mathrm{of} \mathrm{Fe;} 0$ $\mathrm{mg} / \mathrm{L} \mathrm{Mn}$ and $0 \mathrm{mg} / \mathrm{L}$ of $\mathrm{Zn}$.

The electrical conductivity curves were obtained as a function of sodium chloride $(\mathrm{NaCl})$ concentration, in which the desired electrical conductivity $\left(\mathrm{dS} \mathrm{m}{ }^{-1}\right.$ ) was multiplied by $640 \mathrm{mg} \mathrm{L}^{-1}$, according to Richards (1954). The different saline levels were obtained by dissolving sodium chloride $(\mathrm{NaCl})$ in water, that was obtained from the supply system of UFAL, in buckets of $14 \mathrm{~L}$. Saline water that was used for treatments irrigation was verified before each irrigation with the aid of a Portable Digital Conductivity Meter (Mod. Cd-4301).

\subsection{Experimental Design}

The experiment was assessed in three periods at interval of 10 days. Saline treatments were applied three days after the seedlings were established, thus starting the first evaluation period. The experimental design was completely randomized, arranged in a $5 \times 2$ factorial scheme (five salt levels and two lettuce cultivars), with six replicates. The experimental unit was represented by a pot with a plant. The treatments resulted from the combination of five irrigation water salinity levels, as follows: 0.14 (control); $1.54 ; 2.94 ; 4.34$; and $5.74 \mathrm{dS} \mathrm{m}^{-1}$. The effect of irrigation water salinity levels on the analyzed variables was measured through the analysis of variance, whose results of the treatments were studied through polynomial regression analysis. The effect of the cultivars was compared by the Tukey's test at 0.05 probability. Statistical tests were performed using the SISVAR software, version 5.3Build 77 (Ferreira, 2014).

\subsection{Cultivations Conditions}

Initially, seedlings of lettuce (Lactuca sativa L.) of the Saia Véia and Vitória Verdinha varieties were produced in Styrofoam trays with 200 cells, filled with the Bioplant substrate. Seedlings were irrigated daily with water (electrical of conductivity of $\left.0.14 \mathrm{dS} \mathrm{m}^{-1}\right)$ and every 7 days were fertigated $(0.5 \%$ of urea in the trays). The transplanting was performed manually 30 days after sowing (DAS), where seedlings that showed more vigor were selected and transplanted into plastic containers and one plant was conditioned per pot, with seedlings with four to six leaves. As a form of irrigation control, plastic vats with a capacity of five liters were drilled and connected to collecting hoses to conduct the fraction of drained water. Each pot had in the bottom filled with 500 $\mathrm{g}$ of gravel $(3 \mathrm{~cm}$ high) and the remaining volume was completed with soil, totaling $5.5 \mathrm{~kg}$. Pots were placed on a bench at $1.0 \mathrm{~m}$ of distance from the ground level.

The beginning of the experiment was characterized by raising the soil to the field capacity; for this, recipients were saturated with water and wrapped individually in plastic, to force the loss of water only by drainage. When the drainage ceased, the plastic covers were removed and the recipients were weighed on a digital scale $(0.1 \mathrm{~g}$ precision), thus obtaining the control weight, corresponding to the field capacity, which was approximately 6.8 $\mathrm{kg}$ for each recipient; finally, seedlings were transplanted. 
After the beginning of treatments, irrigation was performed twice a day (at 8:00 am and 4:00 p.m.), based on the water consumption of the plants of the previous day, keeping the soil moisture close to the field capacity.

The estimated water volume for daily irrigation was divided by the factor 0.9 , to restore soil moisture to field capacity, also, to obtain a leaching fraction (FL) of $10 \%$, using the following formula: (VI-VD)/(1-FL), where VI: is the volume of water to be applied on the irrigation; VA: is the volume of water applied in the previous irrigation, and VD: is the volume of drained water in the previous irrigation (VI, VA, and VD were described in $\mathrm{mL})$.

\subsection{Physiological Analysis}

The physiological analysis was performed with an infrared gas analyzer IRGA (LI 6400, LICOR, Lincoln, USA), with a photosynthetic photon flux density (PPFD) according to the environment of $800 \mu$ mol photons $\mathrm{m}^{-2} \mathrm{~s}^{-1}$. Analyses were performed between 8:00 a.m. and 10:00 a.m., at 10, 20, and 30 days after the application of treatments (DAAT). In fully expanded and non-senescent leaves, the following measures were performed: net photosynthesis $\left(A-\mu \mathrm{mol} \mathrm{CO} \mathrm{CO}_{2} \mathrm{~m}^{-2} \mathrm{~s}^{-1}\right)$ and transpiration $\left(E\right.$-mmol $\left.\mathrm{H}_{2} \mathrm{O} \mathrm{m}^{-2} \mathrm{~s}^{-1}\right)$ rates, stomatal conductance $\left(g s-\mathrm{H}_{2} \mathrm{O} \mathrm{m}^{-2} \mathrm{~s}^{-1}\right)$, leaf temperature $\left(\mathrm{T}^{\circ} \mathrm{C}\right.$ ), and water use efficiency (WUE- $\mu \mathrm{mol} \mathrm{CO} \mathrm{CO}_{2} \mathrm{mmol}^{-1} \mathrm{H}_{2} \mathrm{O}$ ) through the $A / E$ ratio. The green index (GI) was measured in 10 fully expanded and non-senescent leaves. For each leaf, 10 readings were collected, and a mean of the green index was obtained. The readings were obtained with a Portable Chlorophyll Meter (Model SPAD-502 ${ }^{\circledR}$, Soil Plant Analyzer Development, Minolta, Japan).

\section{Results and Discussion}

\subsection{Data From the Automatic Meteorological Station}

The recorded, for the greenhouse proximal area, where the pots were allocated with the seeds, from germination to the end of the plants' biocycle, temperatures that ranged from 24 to $36^{\circ} \mathrm{C}$ (Figure 1A) and global radiations that ranged from 5 to $28 \mathrm{MJ} \mathrm{m}^{-2}$ day $^{-1}$ (Figure 1B). Inside the greenhouse, the photosynthetically active radiation was measured, ranging from $558 \mu \mathrm{mol} \mathrm{m} \mathrm{m}^{-1}$ from 7:00 a.m. to 11:00 a.m. and $678 \mu \mathrm{mol} \mathrm{m}^{-2} \mathrm{~s}^{-1}$ from 12:00 p.m. to $4: 00$ p.m. The temperature inside the greenhouse ranged from $40{ }^{\circ} \mathrm{C}$ (May) to 28 (June) and relative humidity ranged from 30 to $80 \%$.

The precipitation average for the year of this experiment is in line with the averages recorded for the region, as can be seen in the author's paper Xavier and Dornella (2005), in which municipality of Arapiraca has a rainfall regime concentrated in the autumn-winter period, confirming the regional dynamics. Most of your rainfall precipitates in just 3 months (usually, May, June and July).

In the month in which the experiment started (May), the highest temperature of the year was recorded, a fact that repeated itself at the end of November (Figure 1A), which increased the internal temperature of the greenhouse, as well as the relative humidity. Temperature and relative humidity influence the metabolic functions, transpiration, and mechanisms of thermal control of plants (Teruel, 2010). 
(A)

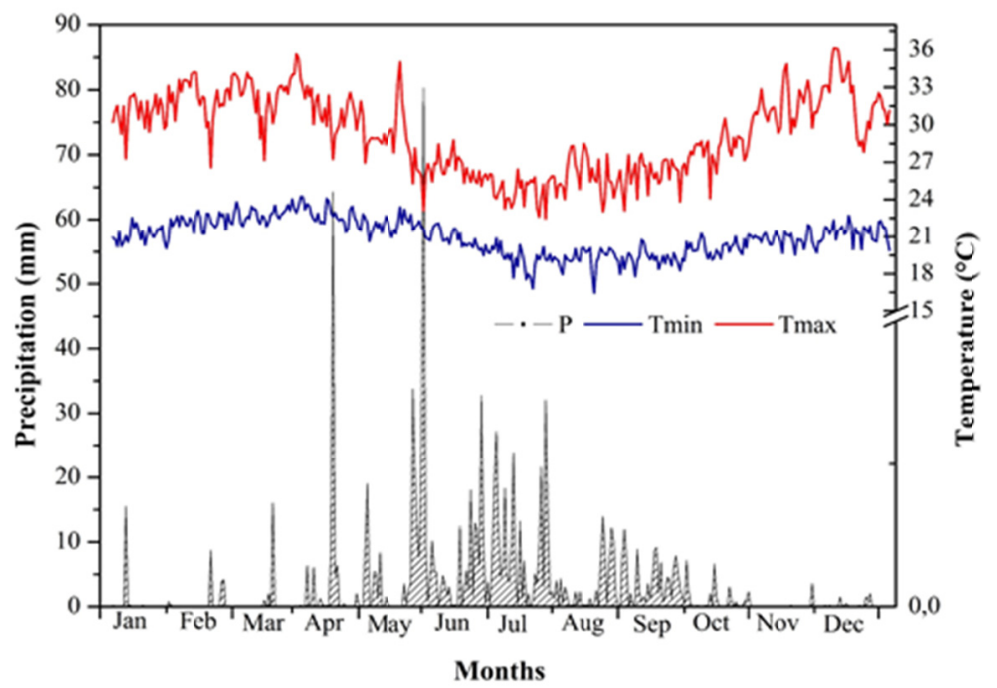

(B)

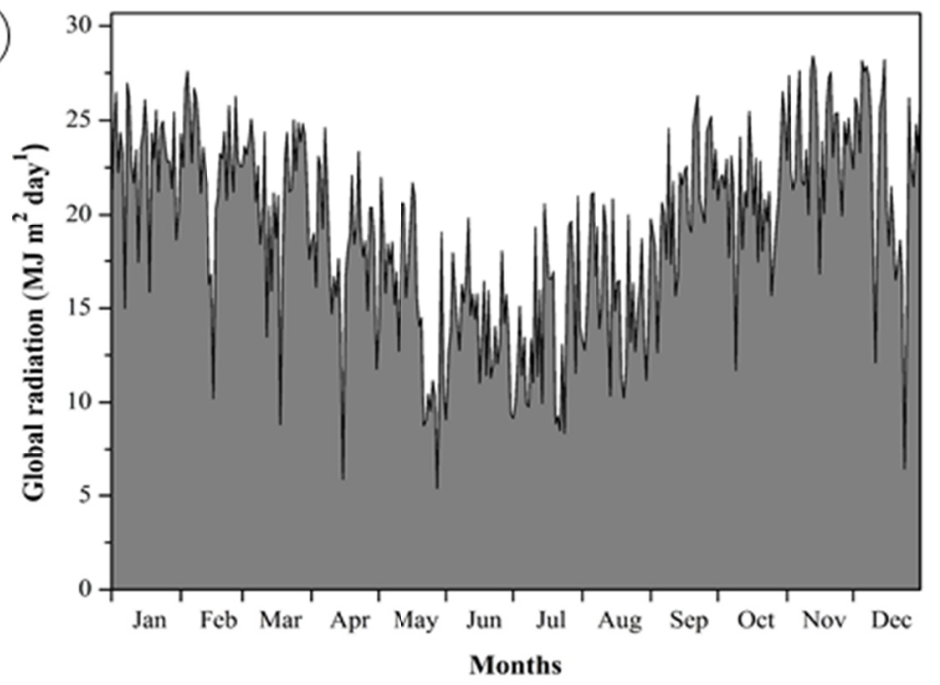

Figure 1. Climatic data obtained from the automatic weather station. A- Maximum and minimum temperatures and precipitation levels recorded in the city of Arapiraca. B- Global radiation registered in the outside area of the greenhouse. Year 2016

\subsection{Physiological Parameters}

There was a significant effect of irrigation water salinity during the gas exchanges in the two lettuce cultivars.

However, there was no interaction between salinity and cultivars. Regarding transpiration rates $(E)$ in both cultivars, the interaction effect was observed only at 20 DAAT (Table 1). 
Table 1. Summary of variance analysis for photosynthesis $(A)$, transpiration $(E)$ and stomatal conductance $(g s)$ for Saia Véia and Vitória verdinha cultivars, as a function of the electrical of conductivity water) of irrigation, at 10, 20 and 30 days after application of treatments (DAAT)

\begin{tabular}{|c|c|c|c|c|c|c|c|c|c|c|}
\hline \multirow{3}{*}{ Sources of Variation } & \multirow{3}{*}{ GL } & \multicolumn{9}{|c|}{ Mean Squares (DAAT) } \\
\hline & & \multicolumn{3}{|c|}{$A$} & \multicolumn{3}{|c|}{$E$} & \multicolumn{3}{|c|}{ GS } \\
\hline & & 10 & 20 & 30 & 10 & 20 & 30 & 10 & 20 & 30 \\
\hline Salinity (S) & 4 & $1.25^{* *}$ & $2.30^{* *}$ & $3.62^{* *}$ & $1.38 * *$ & $2.49^{* *}$ & $3.42^{* *}$ & $0.0001^{* *}$ & $0.0070^{* *}$ & $0.0005^{* *}$ \\
\hline Linear Regression & 1 & $4.90^{* *}$ & $9.16^{* *}$ & $14.20^{* *}$ & $5.48^{* *}$ & $3.85^{* *}$ & $13.46^{* *}$ & $0.0009^{* *}$ & $0.0249^{* *}$ & $0.0020^{* *}$ \\
\hline Quadratic Regression & 1 & $0.01^{\mathrm{NS}}$ & $0.01^{\mathrm{NS}}$ & $0.22^{* *}$ & $0.02^{\mathrm{NS}}$ & $0.06^{* *}$ & $0.18^{* *}$ & $0.0000^{\mathrm{NS}}$ & $0.0020^{\mathrm{NS}}$ & $0.0000^{\mathrm{NS}}$ \\
\hline Deviation regression & 2 & $0.04^{\mathrm{NS}}$ & $0.02^{\mathrm{NS}}$ & $0.03^{\mathrm{NS}}$ & $0.01^{\mathrm{NS}}$ & $0.04 *$ & $0.03^{\mathrm{NS}}$ & $0.0000^{\mathrm{NS}}$ & $0.0005^{\mathrm{NS}}$ & $0.0000^{\mathrm{NS}}$ \\
\hline Cultivar (C) & 1 & $0.01^{\mathrm{NS}}$ & $1.31 * *$ & $1.11^{\mathrm{NS}}$ & $0.15^{\mathrm{NS}}$ & $1.15 * *$ & $0.12 * *$ & $0.0015 * *$ & $0.0366 * *$ & $0.0000^{\mathrm{NS}}$ \\
\hline $\mathbf{S} \times \mathbf{C}$ & 4 & $0.01^{\mathrm{NS}}$ & $0.05^{\mathrm{NS}}$ & $0.01^{\mathrm{NS}}$ & $0.34^{\mathrm{NS}}$ & $0.02 *$ & $0.01^{\mathrm{NS}}$ & $0.0000^{\mathrm{NS}}$ & $0.0034^{\mathrm{NS}}$ & $0.0000^{\mathrm{NS}}$ \\
\hline Residual & 10 & 0.02 & 0.03 & 0.02 & 0.01 & 0.01 & 0.01 & 0.0000 & 0.0009 & 0.0000 \\
\hline CV $(\%)$ & & 0.81 & 0.89 & 0.71 & 1.94 & 1.06 & 1.16 & 0.70 & 8.39 & 1.46 \\
\hline \multicolumn{2}{|l|}{ Salinity (S) } & \multicolumn{3}{|c|}{------ $\mu \mathrm{mol} \mathrm{CO} \mathrm{Cm}_{2} \mathrm{~m}^{-1}$------ } & \multicolumn{3}{|c|}{----- $\mathrm{mmol} \mathrm{H}_{2} \mathrm{O} \mathrm{m}^{-2} \mathrm{~s}^{-1}$} & \multicolumn{3}{|c|}{-- $\mathrm{mol} \mathrm{H}_{2} \mathrm{O} \mathrm{m}^{-2} \mathrm{~s}^{-1}$} \\
\hline $\mathrm{S} 1\left(0.14 \mathrm{dS} \mathrm{m}^{-1}\right)$ & & 16.96 & 19.02 & 20.76 & 6.60 & 7.74 & 8.56 & 0.3074 & 0.4201 & 0.5217 \\
\hline $\mathrm{S} 2\left(1.54 \mathrm{dS} \mathrm{m}^{-1}\right)$ & & 16.66 & 18.45 & 20.45 & 6.29 & 7.00 & 8.07 & 0.3029 & 0.3601 & 0.5144 \\
\hline $\mathrm{S} 3\left(2.94 \mathrm{dS} \mathrm{m}^{-1}\right)$ & & 16.41 & 18.10 & 19.86 & 5.98 & 6.64 & 7.58 & 0.2957 & 0.3511 & 0.5120 \\
\hline $\mathrm{S} 4\left(4.34 \mathrm{dS} \mathrm{m}^{-1}\right)$ & & 15.85 & 17.61 & 19.10 & 5.49 & 6.14 & 7.04 & 0.2922 & 0.3230 & 0.5000 \\
\hline $\mathrm{S} 5\left(5.74 \mathrm{dS} \mathrm{m}^{-1}\right)$ & & 15.61 & 17.05 & 18.45 & 5.15 & 5.69 & 6.18 & 0.2894 & 0.3141 & 0.4937 \\
\hline \multicolumn{11}{|l|}{ Cultivar (C) } \\
\hline C1 (Saia Véia) & & $16.32 \mathrm{a}$ & $18.30 \mathrm{a}$ & $19.72 \mathrm{a}$ & $5.93 \mathrm{a}$ & $6.88 \mathrm{a}$ & $7.56 \mathrm{a}$ & $0.3061 \mathrm{a}$ & $0.3965 \mathrm{a}$ & $0.5094 \mathrm{a}$ \\
\hline C2 (Vitória Verdinha) & & $16.27 \mathrm{a}$ & $17.79 \mathrm{~b}$ & $19.72 \mathrm{a}$ & $5.87 \mathrm{a}$ & $6.40 \mathrm{~b}$ & $7.41 \mathrm{~b}$ & $0.2889 \mathrm{~b}$ & $0.3109 \mathrm{~b}$ & $0.5073 \mathrm{a}$ \\
\hline MSD & & 0.13 & 0.16 & 0.14 & 0.11 & 0.07 & 0.09 & 0.0021 & 0.0295 & 0.0074 \\
\hline
\end{tabular}

Note. (*) Significant at 0.05 and (**) at 0.01 probability; (NS) Not Significant; (MSD) Minimum Significant Difference. Means followed by the same letter do not differ from each other, in columns, by the Tukey test at $\mathrm{p}<$ 0.05 level.

On the other hand, when the isolated effect of salinity levels was analyzed, there was an effect $(\mathrm{p}<0.01)$ for the three variables $(A, E$, and $g s)$ in the different periods assessed, which highlights the direct influence of saline water on growth and development of the two lettuce cultivars (Table 1).

The presence of $\mathrm{NaCl}$ in the irrigation water influenced the photosynthesis of the assessed cultivars only at 20 DAAT, where the cultivar $\mathrm{C} 1$ showed an increase of approximately $3 \%$ in this variable compared to $\mathrm{C} 2$. Compared to $\mathrm{C} 2$, cultivar $\mathrm{C} 1$ showed higher values for $E$ at $20(7 \%)$ and $30(2 \%)$ DAAT and $g s$ at $10(5.6 \%)$ and $20(21.6 \%)$ DAAT (Table 1).

Saline stress caused linear reductions in $g_{s}$ in all assessed periods; however, at 20 DAAT, the decrease was more expressive with approximately 5\% per unit increase of ECW. The decrease of the lowest $\left(0.14 \mathrm{dS} \mathrm{m}^{-1}\right)$ to the highest saline level $\left(5.74 \mathrm{dS} \mathrm{m}^{-1}\right.$ ) was $24.7 \%$ (Figure $2 \mathrm{~A}$ ). 


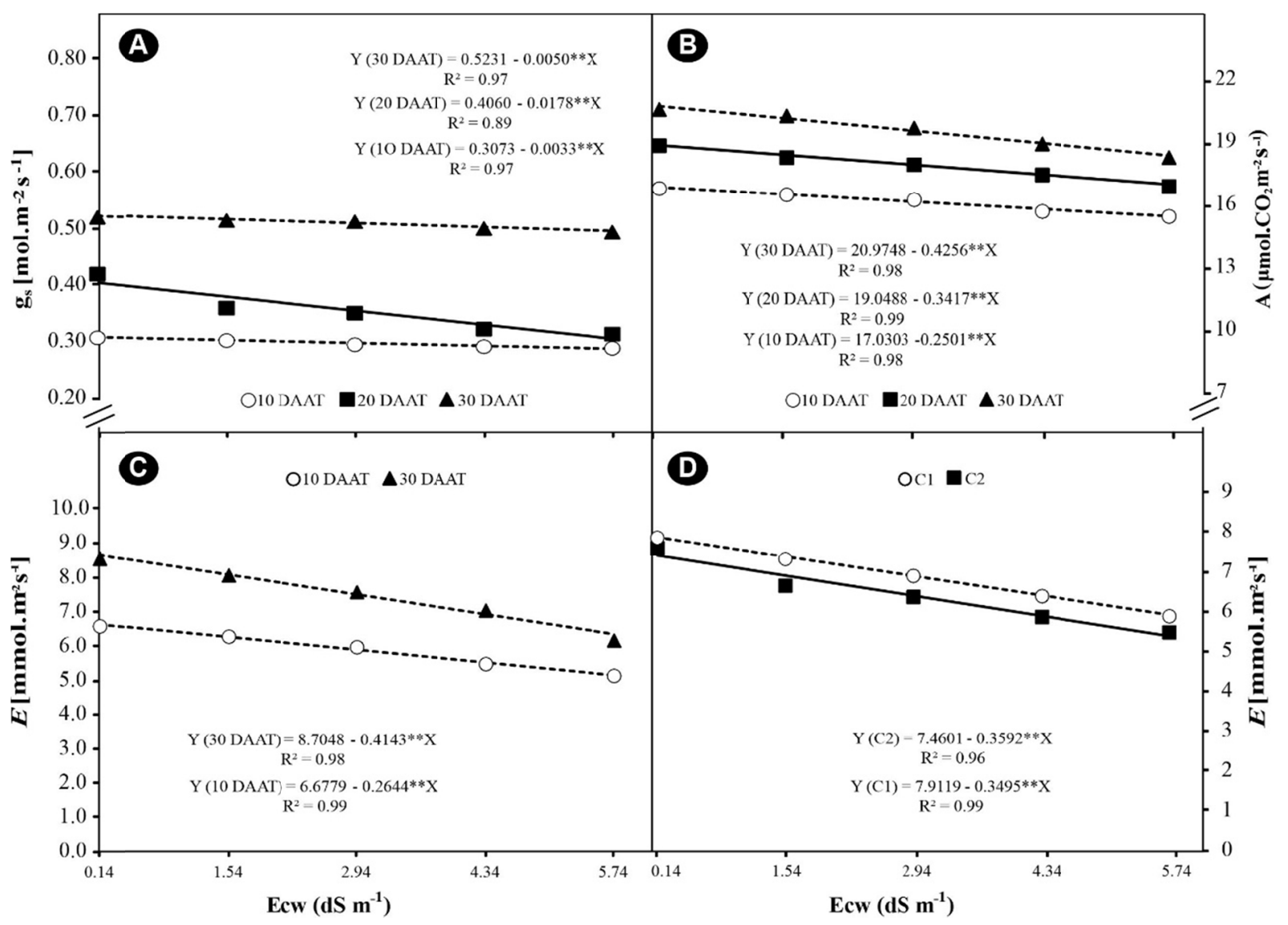

Figure 2. Physiological parameters of two lettuce cultivars submitted to increasing salinity levels. (A) Stomatal conductance, (B) photosynthesis, (C) Transpiration only for salinity levels and (D) Transpiration only cultivars effect

In the photosynthesis analysis, there were linear reductions of $1.5,1.8$, and $4.8 \%$, at 10,20 , and 30 DAAT, respectively (Figure 2B), for each increased unit of ECw. The decrease in the lowest level concerning higher saline levels was $8.2,10$, and $26.8 \%$ at 10,20 , and 30 DAAT, respectively.

The transpiration rate at 10 and 30 DAAT was only effective for the salinity levels, with linear reductions of 4.1 and $4.8 \%$, respectively, for each increased unit of $\mathrm{ECw}$ (Figure 2C). The decrease in the lowest level concerning the highest saline level was 22.3 and $26.8 \%$, respectively, at 10 and 30 DAAT.

At 20 DAAT, cultivars presented linear adjustments, with reductions of 4.5 and $4.9 \%$ with a unit increment of salinity, respectively. The decrease between the lowest and highest saline levels was 24.9 and $27.2 \%$ for $\mathrm{Cl}$ and $\mathrm{C} 2$, respectively (Figure 2D).

In the two cultivars evaluated, the rates of $A$ and $E$ were directly influenced by $g s$. Under conditions of stress, especially water and salt, the stomatal closure can be seen as a positive response of the plant to the maintenance of water balance (Yousifet al., 2010). It is well known that salt stress reduces root hydraulic conductivity resulting in decreased water flow from roots to shoot, even in osmotically adjusted plants (O'Leary, 1969; Prisco \& Gomes-Filho, 2010). This decrease in water flow due to salt stress may cause a lowering in leaf water content, that would result in stomatal closure in order to maintain their water status (Azevedo-Neto et al., 2004). Thus, gs may have been reduced due to lower water availability of the roots (Tatagiba et al., 2014).

Similar results were observed by Han and Lee (2005) in which lettuce plants submitted to salt stress showed severe reductions in $A, E$, and $g s$. Similar results were found by Moles et al. (2016), where severe restrictions on $A$ and $E$ rates were observed in two tomato cultivars submitted to different saline levels.

Water use efficiency (WUE) and leaf temperature (T) were not influenced by the interaction of salinity levels and cultivars (Table 2); however, Green Index (GI) was significant only at 30 DAAT. 
Table 2. Summary of variance analysis for Green Index (GI), Water Use Efficiency (WUE), and Leaf Temperature (LT) of cultivars Saia Véia and Vitória verdinha, as a function of the electrical conductivity of water of irrigation at 10, 20, and 30 days after application of the treatments (DAAT)

\begin{tabular}{|c|c|c|c|c|c|c|c|c|c|c|}
\hline \multirow{3}{*}{ Sources of Variation } & \multirow{3}{*}{ GL } & \multicolumn{9}{|c|}{ Mean Squares (DAAT) } \\
\hline & & \multicolumn{3}{|c|}{$\overline{\text { GI }}$} & \multicolumn{3}{|c|}{ WUE } & \multicolumn{3}{|c|}{$\mathbf{L T}$} \\
\hline & & 10 & 20 & 30 & 10 & 20 & 30 & 10 & 20 & 30 \\
\hline Salinity (S) & 4 & $1.67^{* *}$ & $11.23^{* *}$ & $11.64^{* *}$ & $0.14 * *$ & $0.17^{* *}$ & $0.18^{* *}$ & $1.84^{* *}$ & $2.27^{* *}$ & $4.78^{* *}$ \\
\hline Linear Regression & 1 & $6.64^{* *}$ & $42.03^{* *}$ & $42.03^{* *}$ & $0.54^{* *}$ & $0.69^{* *}$ & $0.68^{* *}$ & $6.78^{* *}$ & $8.61^{* *}$ & $18.53^{* *}$ \\
\hline Quadratic Regression & 1 & $0.02^{\mathrm{NS}}$ & $0.35^{\mathrm{NS}}$ & $3.81^{* *}$ & 0.01 NS & $0.00^{\mathrm{NS}}$ & $0.03 * *$ & $0.00^{\mathrm{NS}}$ & $0.37 *$ & $0.17^{\mathrm{NS}}$ \\
\hline Deviation regression & 2 & $0.00^{\mathrm{NS}}$ & $1.28^{* *}$ & $0.36^{*}$ & $0.00^{\mathrm{NS}}$ & $0.00^{\mathrm{NS}}$ & $0.01 *$ & $0.28^{\mathrm{NS}}$ & $0.04^{\mathrm{NS}}$ & $0.20^{*}$ \\
\hline Cultivars (C) & 1 & $0.04^{\mathrm{NS}}$ & $73.35^{* *}$ & $46.82^{* *}$ & $0.00^{\mathrm{NS}}$ & $0.08^{* *}$ & $0.02 * *$ & $1.88^{* *}$ & $0.02^{\mathrm{NS}}$ & $0.03^{\mathrm{NS}}$ \\
\hline $\mathbf{S} \times \mathbf{C}$ & 4 & $0.04^{\mathrm{NS}}$ & $0.20^{\mathrm{NS}}$ & $1.80^{* *}$ & $0.01^{\mathrm{NS}}$ & $0.00^{\mathrm{NS}}$ & $0.00^{\mathrm{NS}}$ & $0.14^{\mathrm{NS}}$ & $0.02^{\mathrm{NS}}$ & $0.02^{\mathrm{NS}}$ \\
\hline Residual & 10 & 0.05 & 0.09 & 0.05 & 0.00 & 0.00 & 0.00 & 0.17 & 0.05 & 0.04 \\
\hline CV $(\%)$ & & 0.75 & 1.01 & 0.74 & 2.32 & 1.25 & 1,53 & 1.25 & 0.67 & 0.61 \\
\hline \multicolumn{2}{|l|}{ Salinity (S) } & \multicolumn{3}{|c|}{--- Dimensionless greatness --- } & \multicolumn{3}{|c|}{---- $\mathrm{CO}_{2} \mathrm{mmol}^{-1} \mathrm{H}_{2} \mathrm{O}$} & \multicolumn{3}{|c|}{ 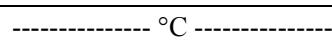 } \\
\hline S1 $\left(0.14 \mathrm{dS} \mathrm{m}^{-1}\right)$ & & 29.95 & 27.58 & 29.03 & 2.57 & 2.46 & 2.42 & 32.39 & 32.53 & 32.71 \\
\hline $\mathrm{S} 2\left(1.54 \mathrm{dS} \mathrm{m}^{-1}\right)$ & & 29.58 & 28.00 & 29.40 & 2.65 & 2.64 & 2.54 & 33.08 & 32.79 & 33.43 \\
\hline $\mathrm{S} 3\left(2.94 \mathrm{dS} \mathrm{m}^{-1}\right)$ & & 29.23 & 30.18 & 30.30 & 2.74 & 2.73 & 2.62 & 33.38 & 33.04 & 33.67 \\
\hline $\mathrm{S} 4\left(4.34 \mathrm{dS} \mathrm{m}^{-1}\right)$ & & 28.75 & 30.65 & 31.05 & 2.89 & 2.87 & 2.71 & 33.45 & 33.77 & 34.77 \\
\hline $\mathrm{S} 5\left(5.74 \mathrm{dS} \mathrm{m}^{-1}\right)$ & & 28.33 & 31.38 & 33.33 & 3.03 & 3.00 & 2.99 & 34.26 & 34.36 & 35.45 \\
\hline \multicolumn{11}{|l|}{ Cultivars (C) } \\
\hline C1 (Saia Véia) & & $29.21 \mathrm{a}$ & $27.64 \mathrm{~b}$ & $29.09 \mathrm{~b}$ & $2.77 \mathrm{a}$ & $2.68 \mathrm{~b}$ & $2.63 \mathrm{~b}$ & $33.00 \mathrm{~b}$ & $33.33 \mathrm{a}$ & $33.97 \mathrm{a}$ \\
\hline C2 (Vitória Verdinha) & & $29.12 \mathrm{a}$ & $31.47 \mathrm{a}$ & $32.15 \mathrm{a}$ & $2.78 \mathrm{a}$ & $2.80 \mathrm{a}$ & $2.69 \mathrm{a}$ & $33.62 \mathrm{a}$ & $33.27 \mathrm{a}$ & $34.04 \mathrm{a}$ \\
\hline MSD & & 0.22 & 0.30 & 0.23 & 0.06 & 0.01 & 0.04 & 0.42 & 0.22 & 0.21 \\
\hline
\end{tabular}

Note. $\left({ }^{*}\right)$ Significant at 0.05 and $(* *)$ at 0.01 probability; (NS) Not Significant; (MSD) Minimum Significant Difference. Means followed by the same letter do not differ from each other, in columns, by the Tukey test at $\mathrm{p}<$ 0.05 level.

When analyzing the isolated effect of salinity levels $(p<0.01)$ for the three variables (GI, WUE, and T), the different evaluation periods were observed, and interaction was observed between salt levels and cultivars exclusively for GI at 30 DAAT. The cultivar factor was significant $(p<0.01)$ at 20 and 30 DAAT. Regarding cultivars $\mathrm{C} 1$ and $\mathrm{C} 2$, higher values were observed for GI 13.9 and $10.5 \%$ at 20 and 30 DAAT, respectively (Table 2).

The variable WUE was influenced by the presence of $\mathrm{NaCl}$ at 20 and $30 \mathrm{DAAT}$, where cultivar $\mathrm{C} 2$ increased by 4.5 and $2.3 \%$, respectively, when compared to $\mathrm{C} 1$ (Table 2). At 10 DAAT, LT was higher for $\mathrm{C} 2$, which presented an increase of $1.9 \%$ about $\mathrm{C} 1$ (Table 2).

At 10 DAAT, each increased unit of ECw showed a linear decrease of $1 \%$ for the outcome GI; this decrease reached 5.3\% when the lowest and highest saline levels were compared (Figure 3A). At 20 DAAT, plants presented a linear increase of $1.5 \%$ at each unit increase of ECw; this increase reached $14.7 \%$ when the lowest and highest saline levels were compared (Figure 3A). 


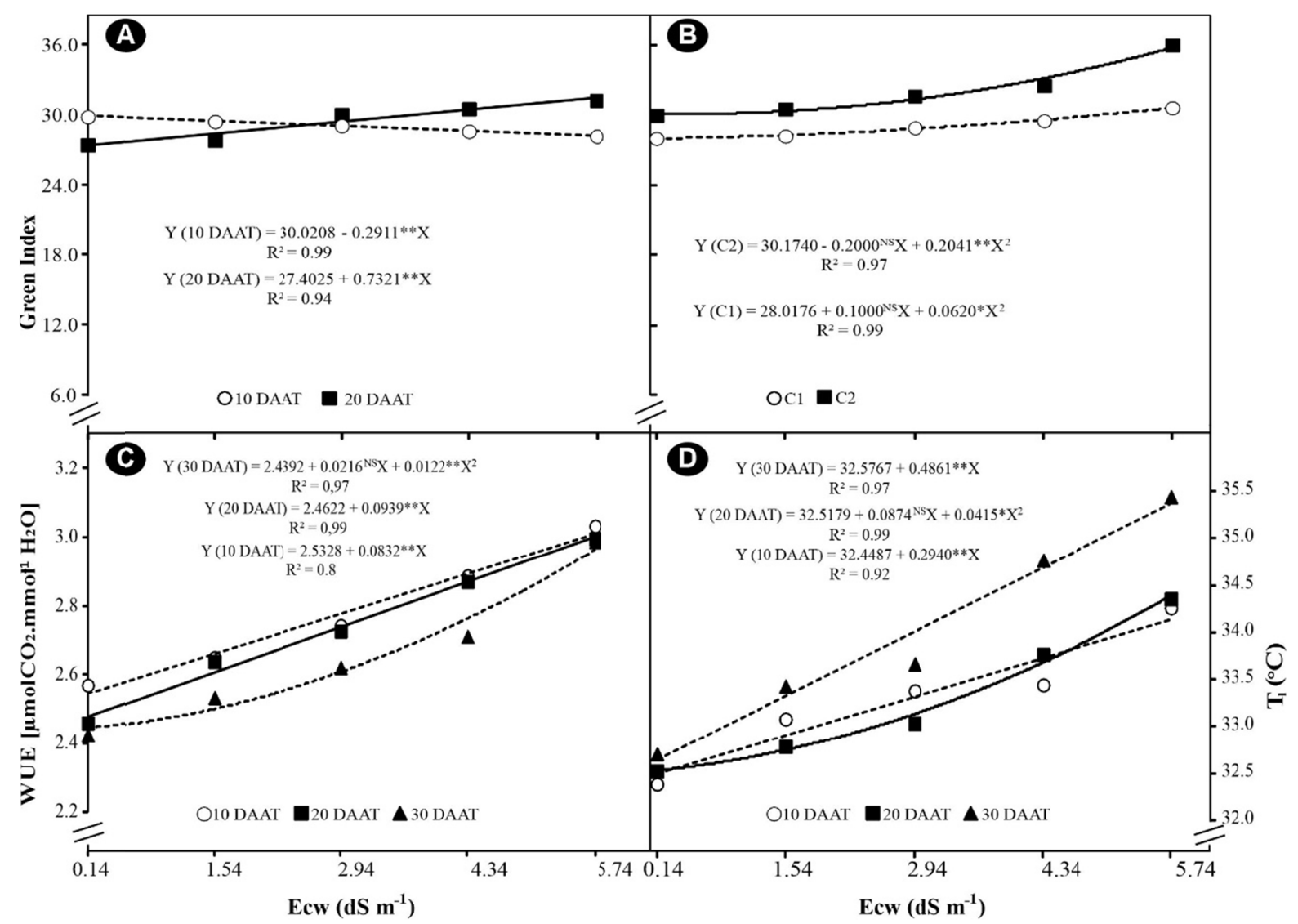

Figure 3. A and B: Green Index (GI), C: Water Use Efficiency (WUE), D: Temperature (T) as a function of the electrical conductivity of the irrigation water, at 10, 20, and 30 days after application of the treatments (DAAT)

At 30 DAAT, the outcome GI was effective $(\mathrm{p}<0.01)$ for the interaction between the salinity levels and the cultivar, in which a linear increase occurred for each increased unit of $\mathrm{ECw}$ in $\mathrm{C} 1$ and $\mathrm{C} 2$ of 2.2 and $3.4 \%$, respectively; also, an increase in GI in $\mathrm{C} 1$ and $\mathrm{C} 2$ of 9.4 and $19.1 \%$ occurred, respectively, from lowest to highest saline levels (Figure 3B).

The intensity and duration of stress progression influence the plant's responses to water scarcity and salinity since these factors influence the processes associated with acclimatization (Chaves et al., 2009). The increase in GI of the plants at 20 DAAT compared to 10 DAAT, suggests acclimatization of the plants to the different levels of $\mathrm{NaCl}$.

The increase in GI shows that the plant can use mechanisms such as a greater thickness of the mesophyll and an increase in the number of thylakoids and chloroplasts, which indicate activation in the process of protection to the photosynthetic apparatus (Lacerda et al., 2006).

Some studies showed that increases in GI were observed in response to salt stress in Vigna unguiculta L. (Lacerda et al., 2006) and Arachis hypogaea L. (Graciano et al., 2011); on the other hand, Vigna unguiculta L (Praxedes et al., 2009) showed a reduction in GI, which might be attributed to a weakening of the pigment-protein complex in most sensitive cultivars due to exposure to salinity (Taffouo et al., 2009).

WUE rates were inversely proportional to $\mathrm{A}$ and $\mathrm{E}$ at all assessments, confirming the effects of saline stress with linear increases at all periods (Figures 2B, C, D, and 3C). There was a unit increase of $\mathrm{ECw}$ of 3.3, 3.8, and 3.9\% for 10, 20, and 30 DAAT, respectively. Regarding the lowest and highest saline levels, values of 18.3, 21.3, and $21.8 \%$ were obtained at 10, 20, and 30 DAAT, respectively (Figure 2C).

The increase in the influence of salt levels to WUE was reported for two tomato cultivars (Moles et al., 2016) and Citrus plants (Syvertsen et al., 2010) under different saline levels. This evidence sustains the hypothesis that an increase in WUE, under salt stress, can be interpreted as a mechanism of tolerance to $\mathrm{NaCl}$ in lettuce plants. 
The increase in the electrical conductivity of water promoted linear increases in leaf temperature in all evaluated periods (Table 2). However, at 30 DAAT, there was an increase for each unit increase of $\mathrm{ECw}$ of $1.5 \%$, with a rise in temperature from the lowest to the highest salt levels of $8.3 \%$, equivalent to $2.7^{\circ} \mathrm{C}$ (Figure 2D).

In Figure 4, it is possible to observe at 30 days after the application of saline levels the aspect of each cultivar and it is noticeable that the cv 'Vitória Vedinha', has superior green index (visual aspect), however, the cv 'Saia Véia' has with physiological performance higher.

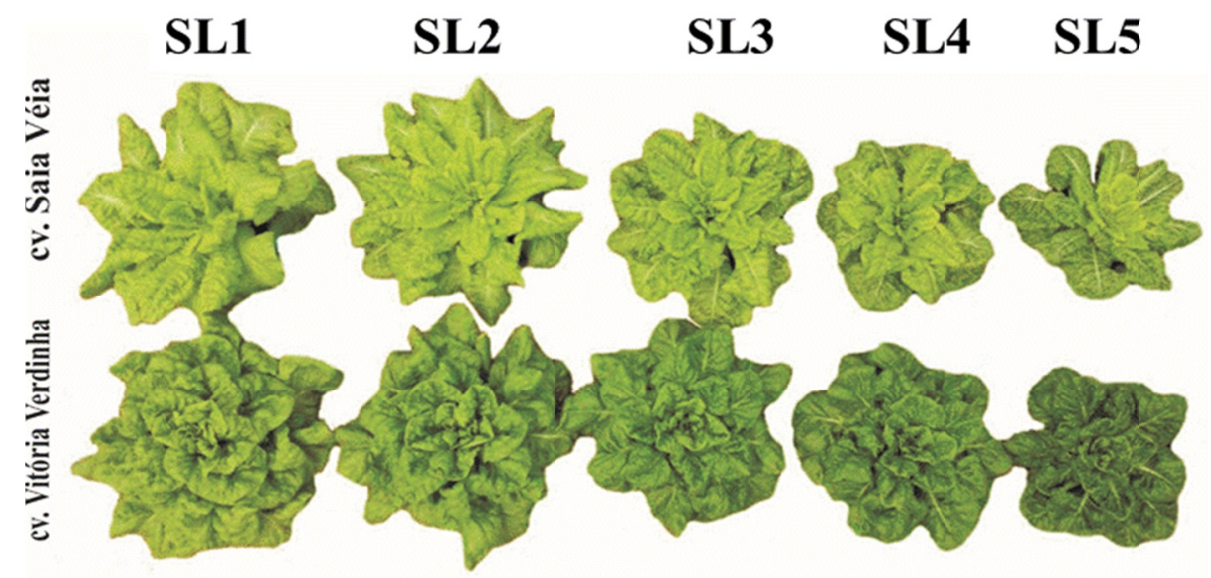

Figure 4. Morphological aspect of the two varieties of lettuce submitted to different saline levels 30 days after treatments. SL: Saline Level. $1=0.14 ; 2=1.54 ; 3=2.94 ; 4=4.34$ and $5=5.74 \mathrm{dS} \mathrm{m}^{-1}$

The results of the present study were similar to those described by Viana et al. (2004), who observed that an increase in salinity may promote leaf temperature elevation, since by osmotic effect, the restriction of the water flow towards the soil - plant - atmosphere and, consequently, transpiration, resulting in elevation of LT.

\section{Conclusion}

The cv. Saia Véia was higher values of gs, $A$, and $E$, whereas cv. Vitoria Verdinha showed higher tolerance to salt stress, indicated by the higher values of WUE and GI in different levels of $\mathrm{NaCl}$. Results from the present study highlight the need for new studies regarding the genetic improvement of the species so breeders can find genes that can be cloned and later incorporated into new extremely productive varieties, that are not yet sensitive or not tolerant to different levels of saline soil or irrigation water.

\section{Acknowledgements}

The authors thank the Foundation for Research Support of Alagoas (FAPEAL) for the financial support, through the grant to this research in the form of a scholarship process number 23038.007934/2010.

\section{References}

Abuelgasim, A., \& Ammad, R. (2019). Mapping soil salinity in arid and semi-arid regions using Landsat 8 OLI satellite data. Remote Sensing Applications: Society and Environment, 13, 415-425. https://doi.org/10.1016/ j.rsase.2018.12.010

Amorim, A. V., Gomes-Filho, E., Bezerra, M. A., Prisco, J. T., \& Lacerda, C. F. (2010). Respostas fisiológicas de plantas adultas de cajueiro anão precoce à salinidade. Revista Ciência Agronômica, 4l(1), 113-121.

Ayers, R. S., \& Westcot, D. W. (1991). A qualidade da água na agricultura. Campina Grande: UFPB.

Azevedo Neto, A. D., Prisco, J. T., Enéas-Filho, J., Lacerda, J., Claudivan Feitosa, J., Silva, J. V., Costa, P. H. A., \& Gomes-Filho, E. (2004). Effects of salt stress on plant growth, stomatal response and solute accumulation of different maize genotypes. Brazilian Journal of Plant Physiology, 16(1), 31-38. https://doi.org/10.1590/ S1677-04202004000100005

Chaves, M. M., Flexas, J., \& Pinheiro, C. (2009). Photosynthesis under drought and salt stress: Regulation mechanisms from whole plant to cell. Annals of Botany, 103(4), 551-560. https://doi.org/10.1093/ aob/men 125 
Colombani, N., Mastrocicco, M., \& Giambastiani, B. M. S. (2015). Predicting salinization trends in a lowland coastal aquifer: Comacchio (Italy). Water Resour. Manag., 29, 603-618. https://doi.org/10.1007/s11269014-0795-8

Daliakopoulos, I. N., Tsanis, I. K., Koutroulis, A., Kourgialas, N. N., Varouchakis, A. E., Karatzas, G. P., \& Ritsema, C. J. (2016). The threat of soil salinity: A European scale review. Science of The Total Environment, 573, 727-739. https://doi.org/10.1016/j.scitotenv.2016.08.177

Dubreuil, V., Fante, K. P., Planchon, O., \& Sant'anna Neto, J. L. (2018). Os tipos de climas anuais no Brasil: uma aplicação da classificação de Köppen de 1961 a 2015. Confins, 37, 1-23. https://doi.org/10.4000/ confins. 15738

Ferreira, D. F. (2014). SISVAR: A computer statistical analysis system. Ciência e Agrotecnologia, 35(6), 1039-1042. https://doi.org/10.1590/S1413-70542011000600001

Flowers, T. J. (2004). Improving crop salt tolerance. Journal of Experimental Botany, 55(396), $307-319$. https://doi.org/10.1093/jxb/erh003

Flowers, T. J., Galal, H. K., \& Bromham, L. (2010). Evolution of halophytes: Multiple origins of salt tolerance in land plants. Functional Plant Biology, 37(7), 604-612. https://doi.org/10.1071/FP09269

Gheyi, H. R., Queiroz, J. E., \& Medeiros, J. F. (1997). Manejo e controle da salinidade na agricultura irrigada. Campina Grande, UFPB.

Graciano, E. S. A., Nogueira, R. J. M. C., Lima, D. R. M., Pacheco, C. M., \& Santos, R. C. (2011). Crescimento e capacidade fotossintética da cultivar de amendoim BR 1 sob condições de salinidade. Revista Brasileira de Engenharia Agrícola e Ambiental, 15, 94-800. https://doi.org/10.1590/S1415-43662011000800005

Han, H. S., \& Lee, K. D. (2005). Plant growth-promoting rhizobacteria effect on antioxidant status, photosynthesis, mineral uptake, and growth of lettuce under soil salinity. Research Journal of Agriculture and Biological Sciences, 1(3), 210-215.

Köppen, W. (1948). Climatologia: Con un estudio de los climas de latierra. Fondo de Cultura Econômica, México.

Lacerda, C. F., Assis Júnior, J. O., Lemos Filho, L. C. A., Oliveira, T. S., Guimarães, F. V. A., Gomes-Filho, E., ... Bezerra, M. A. (2006). Morpho-physiological responses of cowpea leaves to salt stress. Brazilian Journal of Plant Physiology, 18, 455-465. https://doi.org/10.1590/S1677-04202006000400003

Medeiros, J. F., Nascimento, I. B., \& Gheyi, H. R. (2016). Manejo do solo-água-planta em área afetadas por sais. In H. R. Gheyi, N. S. Dias, \& C. F. Lacerda (Eds.), Manejo da salinidade na agricultura: Estudos básicos e aplicados. Instituto Nacional de Ciência e Tecnologia em Salinidade, Fortaleza.

Moles, T. M., Pompeiano, A., Reyes, T. H., Scartazza, A., \& Guglielminetti, L. (2016). The efficient physiological strategy of a tomato landrace in response to short-term salinity stress. Plant Physiology and Biochemistry, 109, 262-272. https://doi.org/10.1016/j.plaphy.2016.10.008

Munns, R., \& Tester, M. (2008). Mechanisms of salinity tolerance. Annual Review of Plant Biology, 59, 651-681. https://doi.org/10.1146/annurev.arplant.59.032607.092911

O’Leary, J. W. (1969). The effect of salinity on the permeability of roots to water. Israel Journal of Botany, 18, $1-9$.

Parida, A. K., \& Das, A. B. (2005). Salt tolerance and salinity effects on plants: Review. Ecotoxicology and Environmental Safety, 60(3), 324-349. https://doi.org/10.1016/j.ecoenv.2004.06.010

Pedrotti, A., Chagas, R. M., Ramos, V. C., Prata, A. P. N., Lucas, A. A. T., \& Santos, P. B. (2015). Causas e consequências do processo de salinização dos solos. Revista Eletrônica em Gestão, Educação e Tecnologia Ambiental, 19(2), 1308-1324. https://doi.org/10.5902/2236117016544

Praxedes, S., Ferreira, T., \& Gomes Filho, E. (2009). Acúmulo de prolina e aminoácidos em cultivares de feijão caupi com tolerância diferencial à salinidade. Revista Caatinga, 22(3), 211-214.

Prisco, J. T., \& Gomes-Filho, E. (2010). Fisiologia e bioquímica do estresse salino em plantas. In H. R. Gheyi, N. S. Dias, \& C. F. Lacerda (Eds.), Manejo da salinidade na agricultura (p. 472). Fortaleza, INCT Sal.

Qadir, M., Tubeileh, A., Akhtar, J., Larbi, A., Minhas, P. S., \& Khan, M. A. (2008). Productivity enhancement of salt-affected environments through crop diversification. Land Degrad, 19, 429-453. https://doi.org/10.1002/ ldr. 853 
Qin, J., Dong, W. Y., He, K. N., Yu, Y., Tan, G. D., Han, L., ... Wang, Z. L. (2010). NaCl salinity-induced changes in water status, ion contents, and photosynthetic properties of Shepherdia argentea (Pursh) Nutt. seedlings. Plant, Soil and Environment, 56(7), 325-332. https://doi.org/ 10.17221/209/2009-PSE

Ribeiro, M. R., Freire, F. J., \& Montenegro, A. A. A. (2003). Solos halomórficos no Brasil: Ocorrência, gênese, classificação, uso e manejo sustentável. In N. Curi, J. J. Marques, L. R. G. Guilherme, J. M. Lima, A. S. Lopes \& V. H. Alvarez (Eds.), Tópicos em Ciência do Solo. Viçosa: Sociedade Brasileira de Ciência do Solo.

Richards, L. A. (1954). Diagnosis and improvement of saline and alkaline soils. Washington: U.S. Salinity Laboratory, USDA.

Ruan, C. J., da Silva, J. A. T., Mopper, S., Qin, P., \& Lutts, S. (2010). Halophyte improvement for a salinized world. Critical Reviews in Plant Sciences, 26(6), 329-359. https://doi.org/10.1080/07352689.2010.524517

Seddon, A. W. R., Macias-Fauria, M., Long, P. R., Benz, D., \& Willis, K. J. (2016). Sensitivity of global terrestrial ecosystems to climate variability. Nature, 531, 229-232. https://doi.org/10.1038/nature16986

Syvertsen, J. P., Melgar, J. C., \& Garcia-Sanchez, F. (2010). Salinity tolerance and leaf water use efficiency in citrus. Journal of the American Society for Horticultural Science, 135(1), 33-39. https://doi.org/10.21273/ JASHS.135.1.33

Taffouo, V. D., Kouamou, J. K., Ngalanque, L. M. T., Ndjeudji, B. A. N., \& Akoa, A. (2009). Effects of salinity stress on growth, ions partitioning and yield of some cowpea (Vigna unguiculata L. Walp.) cultivars. International Journal of Botany, 5(1), 135-143. https://doi.org/10.3923/ijb.2009.135.143

Tatagiba, S. D., Moraes, G. A. B. K., Nascimento, K. J. T., \& Peloso, A. F. (2014). Limitações fotossintéticas em folhas de plantas de tomateiro submetidas a crescentes concentrações salinas. Engenharia na Agricultura, 22(2), 138-149. https://doi.org/10.13083/reveng.v22i2

Tavakkoli, E., Paull, J., Rengasamy, P., \& Mcdonald, G. K. (2012). Comparing genotypic variation in faba bean (Vicia faba L.) in response to salinity in hydroponic and field experiments. Field Crops Research, 127, 99-108. https://doi.org/10.1016/j.fcr.2011.10.016

Teruel, B. (2010). Controle automatizado de casas de vegetação: Variáveis climáticas e fertirrigação. Revista Brasileira de Engenharia Agrícola, 14(3), 237-245. https://doi.org/10.1590/S1415-43662010000300001

Viana, S. B. A., Fernandes, P. D., Gheyi, H. R., Soares, F. A. L., \& Carneiro, P. T. (2004). Índices morfofisiológicos e de produção de alface sob estresse salino. Revista Brasileira de Engenharia Agrícola e Ambiental, 8(1), 23-30. https://doi.org/10.1590/S1415-43662004000100004

Walter, J., Lück, E., Bauriegel, A., Facklam, M., \& Zeitz, J. (2018). Seasonal dynamics of soil salinity in peatlands: A geophysical approach. Geoderma, 310, 1-11. https://doi.org/10.1016/j.geoderma.2017.08.022

Xavier, R. A., \& Dornellas, P. C. (2005). Análise do comportamento das chuvas do município de Arapiraca, Região Agreste de Alagoas. Geografia, 14(2), 49-64. https://doi.org/10.5433/2447-1747.2005v14n2p49

$\mathrm{Xu}, \mathrm{C}$., \& Mou, B. (2015). Evaluation of lettuce genotypes for salinity tolerance. Hortscience, 50(10), 1441-1446. https://doi.org/10.21273/HORTSCI.50.10.1441

Yousif, B. S., Nguyen, T. N., Fukuda, Y., Hakata, H., Okamoto, Y., Masaoka, Y., \& Saneoka, H. (2010). Effect of salinity on growth, mineral composition, photosynthesis and water relations of two vegetable crops; New Zealand Spinach (Tetragonia tetragonioides) and Water Spinach (Ipomoea aquatica). International Journal of Agriculture and Biology, 12(2), 211-216.

\section{Copyrights}

Copyright for this article is retained by the author(s), with first publication rights granted to the journal.

This is an open-access article distributed under the terms and conditions of the Creative Commons Attribution license (http://creativecommons.org/licenses/by/4.0/). 